\title{
SISTEM INFORMASI DESA UNTUK MANAJEMEN DATA COVID 19 DAN TRANSPARANSI KEUANGAN DALAM PENINGKATAN EFISIENSI BIROKRASI PEMERINTAH DESA MASBAGIK SELATAN
}

\author{
(Information System for Village of Covid-19 Data Management And Monetary \\ Transparancy Under Improvement of Bureaucracy)
}

\author{
Ferry Zaini Firdhaus ${ }^{[1]}$, Royana Afwani ${ }^{[1]}$, Ali Imran ${ }^{[2]}$ \\ ${ }^{[1]}$ Dept Informatics Engineering, Mataram University \\ J1. Majapahit 62, Mataram, Lombok NTB, INDONESIA \\ ${ }^{[2]}$ Kantor Desa Masbagik Selatan \\ Jl. Jurusan Masbagik Pancor Kode Pos 83661 \\ Email: feri.zaini@gmail.com, royana@unram.ac.id, ali.imran84@gmail.com
}

\begin{abstract}
Abstrak
Secara geografis, Desa Masbagik Selatan termasuk wilayah yang sebagian besar dataran sedang. Letak Desa Masbagik Selatan berada diantara 4 desa lain yang juga masih termasuk dalam wilayah Kecamatan dan satu desa yang termasuk wilayah Kecamatan Sukamulia. Pemerintahan Desa masbagik Selatan dimulai sejak tahun 1913, dengan kepala desa pemerintahan desa pertama yaitu H.M.SAID yang memerintah pada tahun 194. Pada tahun 2018 sampai sekarang, kepala desa dipimpin oleh H. Wiriyawan. Pada segi pembangunan yang terjadi di Desa Masbagik Selatan, dari tahun ke tahun mengalami banyak peningkatan baik di bidang ekonomi, sosial, maupun lingkungan. Berkaitan dengan manajemen birokrasi dan transparansi keuangan yang telah dilaksanakan di Desa Masbagik Selatan masih bersifat manual, sedangkan permasalahan pada masa pandemi Coronavirus dimana segala kegiatan yang berkaitan dengan birokrasi Desa Masbagik Selatan mengalami hambatan. Banyak pasien yang berasal dari wilayah desa Masbagik Selatan. Dikarenakan hal tersebut, maka desa Masbagik Selatan perlu membuat sebuah sistem informasi yang mempunyai fitur manajemen Coronavirus dan transparansi keuangan. Hasil yang diperoleh dari pembuatan Sistem Informasi didapatkan persentase hasil dari pernyataan responden yaitu Sangat Setuju sebesar 64\% atau sebanyak 32 poin dan responden yang memilih setuju sebanyak $36 \%$ atau 18 poin.
\end{abstract}

Keywords: Sistem Informasi Desa, Aplikasi Web, Teknologi Informasi, Masbagik Selatan, Rapid Application Design, Data Covid-19, Keuangan Desa.

\section{Pendahuluan}

\subsection{Latar Belakang}

Tahun 2020 merupakan tahun dimana perkembangan teknologi semakin maju yang menyebabkan seluruh aktivitas manusia seperti pekerjaan perkantoran dan sebagainya semakin dipermudah dengan kehadiran teknologi digital saat ini, yang secara langsung mempengaruhi efisiensi dari pekerjaan yang dikerjakan. Peranan dari teknologi digital dalam membantu pekerjaan dibidang swasta maupun pemerintahan negeri seperti membantu dalam mendapatkan informasi dengan cepat ataupun mendata suatu informasi, teknologi mampu mengolah suatu data dengan efisien dan sekuensial sehingga mampu memberi manfaat bagi pengguna teknologi informasi khususnya dibidang birokrasi pemerintahan. Pengolahan data perlu dilakukan pada setiap instansi ataupun organisasi yang mana data yang diperoleh bernilai informatif mampu meningkatkan efisiensi produktivitas pekerjaan, waktu dan biaya. Sementara disatu sisi keadaan sekarang dimana dunia sedang menghadapi pandemi COVID 19 yang menyebabkan seluruh aktivitas manusia terhambat dan mempengaruhi aktivitas salah satu contoh yang ada pada birokrasi berkaitan antara penduduk desa dengan kantor Desa Masbagik Selatan.

Sistem Informasi Desa yang dikembangkan merupakan suatu Open Source Project yang bernama OpenSID yang dipelopori oleh Komunitas Perkumpulan OpenDesa. Desa Masbagik Selatan masih belum mengimplementasikan suatu Sistem Informasi Desa dimana setiap pekerjaan yang berkaitan khususnya pada Birokrasi dan Administrasi Desa contohnya pada publikasi data keuangan maupun data persebaran infeksi Covid 19 masih dikerjakan secara manual oleh staff Desa Masbagik Selatan. Hal ini menyebabkan setiap proses pekerjaan 
yang berkaitan pada birokrasi maupun administrasi agak lamban khususnya pada publikasi persebaran data Covid19 dan publikasi data keuangan dalam peningkatan tata kelola pemerintahan desa yang berbasis Good Governance yang terkait pada akuntabilitas dan keterbukaan pada setiap penyelenggaraan Pemerintahan Desa Masbagik Selatan. Sistem Informasi Desa yang diimplementasikan di Desa Masbagik Selatan menggunakan metode Rapid Application Design yaitu suatu metode pengembangan sistem yang berfokus pada pengembangan aplikasi secara cepat, melalui pengulangan dan feedback ( umpan balik ) berasal dari staff desa, Kepala Dusun, Sekertaris Desa, dan Kepala Desa.

\subsection{Rumusan Masalah}

Berdasarkan latar belakang yang telah dipaparkan, maka dapat ditranslasikan pokok permasalahannya yaitu :.

a. Bagaimana merancang suatu sistem informasi desa untuk mempermudah operator staf desa dalam proses birokrasi Pemerintahan Desa Masbagik Selatan dalam menciptakan transparansi informasi seperti keuangan desa dan korban COVID 19 ?

b. Bagaimana cara mengelola dan menyajikan sistem informasi desa yang dapat membantu operator staf Kantor Desa Masbagik Selatan seperti data statistik kependudukan, data keuangan, data bantuan, atau data korban COVID 19 agar bisa dipahami ?

\subsection{Tujuan}

Tujuan dari pembuatan Sistem Informasi Desa Masbagik Selatan ini adalah :

a. Merancang suatu fitur Sistem Informasi Desa Masbagik Selatan untuk mempermudah operator staf desa, Satgas Covid-19 dan Kepala Desa memanfaatkan Sistem Informasi berbasis metode Rapid Application Development

b. Mengelola dan menyajikan sistem informasi untuk membantu operator staf desa seperti data statistik kependudukan, data analisa, data pemetaan infografis, data keuangan, pelayanan surat menyurat, data bantuan, serta data statistic COVID 19 menggunakan web dengan Bahasa Pemrograman PHP dengan framework CodeIgniter.

\subsection{Manfaat}

Manfaat dari pembuatan dan pengembangan Sistem Informasi Desa Masbagik Selatan adalah sebagai berikut :

Bagi Operator Staff Desa Masbagik Selatan :

a. Dengan adanya Sistem Informasi Desa Masbagik Selatan, operator akan lebih mudah mengelola data statistik kependudukan, data Analisa, data pemetaan infografis, data keuangan, pelayanan surat menyurat, data bantuan serta data statistic COVID 19 secara daring berbasis web.

b. Mempermudah proses birokrasi Pemerintahan Desa Masbagik Selatan secara efektif dan efisien apabila dibandingkan dengan mekanisme secara manual

Bagi Mahasiswa :

a. Pada proses pembuatan dan pengembangan Sistem Informasi Desa Masbagik Selatan, mahasiswa dapat menambah pemahaman dalam pembuatan dan pengembangan web menggunakan framework CodeIgniter dengan konsep MVC.

b. Menambah pengalaman mahasiswa dalam bekerja pada suatu instansi khususnya birokrasi Pemerintahan Desa Masbagik Selatan.

\section{TINJAUAN PUStaka}

\subsection{Referensi Terkait}

Sebagai bahan referensi dalam pembuatan Sistem Informasi Desa untuk Manajemen Data COVID 19 Dan Transparansi Keuangan Dalam Peningkatan Efisiensi Birokrasi Pemerintah Desa Masbagik Selatan, maka terdapat beberapa jurnal terkait dengan pengembangan Sistem Informasi ini, diantaranya :

a. Pengembangan Sistem Informasi berkaitan Persebaran (COVID 19) yaitu pada jurnal berjudul Implementasi Web Service untuk Aplikasi Pemantau Coronavirus Disease 2019, tentang pengembangan Sistem Informasi Pendataan Persebaran Covid-19 secara realtime. Diperlukan interkoneksi antara platform yang berbeda, untuk mengatasi interoperabilitas antara aplikasi berbasis web dan mobile dapat memanfaatkan teknologi Web Service (WS). Hasil dari penelitian ini menciptakan dua produk yaitu web service Covid-19 yang dapat dimanfaatkan lagi bagi layanan lain. Aplikasi Pemantauan Coronavirus (Covid-19) dapat digunakan oleh masyarakat secara interaktif dan realtime [1]. 
b. Referensi terkait dengan Transparansi Keuangan Desa yaitu pada jurnal berjudul Peranan Sistem Keuangan Desa (SISKEUDES) Terhadap Kinerja Pemerintahan Desa, Studi Kasus di Desa Kaba-Kaba, Kecamatan Kediri, Kabupaten Tabanan, Provinsi Bal. Jurnal penelitian ini menunjukkan bahwa penginputan data pada Sistem Keuangan Desa (Siskeudes) harus sesuai dengan yang tertera dalam system, penerapan Sistem keuangan Desa (Siskeudes) memberikan dampak positif terhadap kinerja pegawai. Hal ini sesuai dengan tujuan diterapkannya Sistem Keuangan Desa (Siskeudes) yaitu membantu kerja pegawai desa [2].

\subsection{Sistem Informasi}

Sistem informasi adalah kumpulan dari subsistem apapun baik fisik ataupun non-fisik yang saling berhubungan satu sama lain dan bekerja sama secara harmonis untuk mencapai satu tujuan yaitu mengolah data menjadi informasi yang memiliki arti dan berguna[3].

\subsection{Database / ERD}

ERD (Entity Relationship Diagram) adalah sebuah diagram yang digunakan dalam merancang hubungan antar tabel-tabel dalam basis data. ERD (Entity Relation diagram) berfungsi untuk menggambarkan gambaran dari dunia nyata yang akan diterapkan pada suatu database di sebuah system [4]

\subsection{Aplikasi Berbasis Web dan Web Server}

Web server merupakan software dalam server yang berfungsi untuk menerima permintaan request berupa halaman web melalui HTTP atau HTTPS dari klien yang dikenal dengan web browser dan mengirimkan kembali hasilnya dalam bentuk halaman-halaman web yang umumnya berbentuk dokumen HTML [6].

PHP (Hypertext Preprocessor) disebut sebagai bahasa pemrograman server side karena diproses pada komputer server saja. Dengan menggunakan PHP, pembuatan web dimudahkan dalam membuat konten di dalam sebuah halaman karena lebih efektif. Misalnya, untuk melakukan pengulangan secara lebih efektif,meng-input database, dan sebagainya [5].

\subsection{Framework CodeIgniter}

CodeIgniter merupakan sebuah framework php yang bersifat open source dan menggunakan metode MVC (Model, View, Controller) untuk memudahkan developer atau programmer dalam membangun sebuah aplikasi berbasis web tanpa harus membuatnya dari awal [7].

\section{Metode Pengabdian masyarakat}

\subsection{Identifikasi Masalah}

Metode pelaksanaan dari kegiatan pengabdian ini diawali dengan melakukan pengidentifikasian masalah dengan turun langsung ke masyarakat atau instansi tempat dengan melaksanakan diskusi terbuka mengenai pengembangan Sistem Informasi . Adapun Lokasi Pelaksanaan kegiatan yaitu Kantor Desa Masbagik Selatan. Berdasarkan pengidentifikasian masalah, didapatkan bahwa Kantor Desa Masbagik Selatan sampai saat ini masih belum memiliki Sistem Informasi Desa Untuk Memproses Data Administrasi khususnya Manajemen Persebaran Data Coronavirus Disease 19 (COVID 19) dan Juga Keuangan Desa.

\subsection{Pengumpulan Data}

Setelah beberapa permasalahan telah berhasil teridentifikasi selanjutnya dilaksanakan pengumpulan data untuk mendukung perancangan sistem. Pengumpulan data dilakukan melalui studi literatur dan studi lapangan. Studi literatur dilakukan dengan mengumpulkan informasi yang dibutuhkan dari buku dan jurnal-jurnal penelitian yang telah dilakukan sebelumnya. Studi lapangan dilakukan dengan melakukan peninjauan langsung di Kantor Desa Masbagik Selatan untuk mengetahui permasalahan yang terjadi di lapangan. Pengumpulan data dilaksanakan dengan wawancara dan kursus bersama Kepala Desa, Sekertaris Desa, beberapa staf desa serta Masyarakat Desa Masbagik Selatan. 


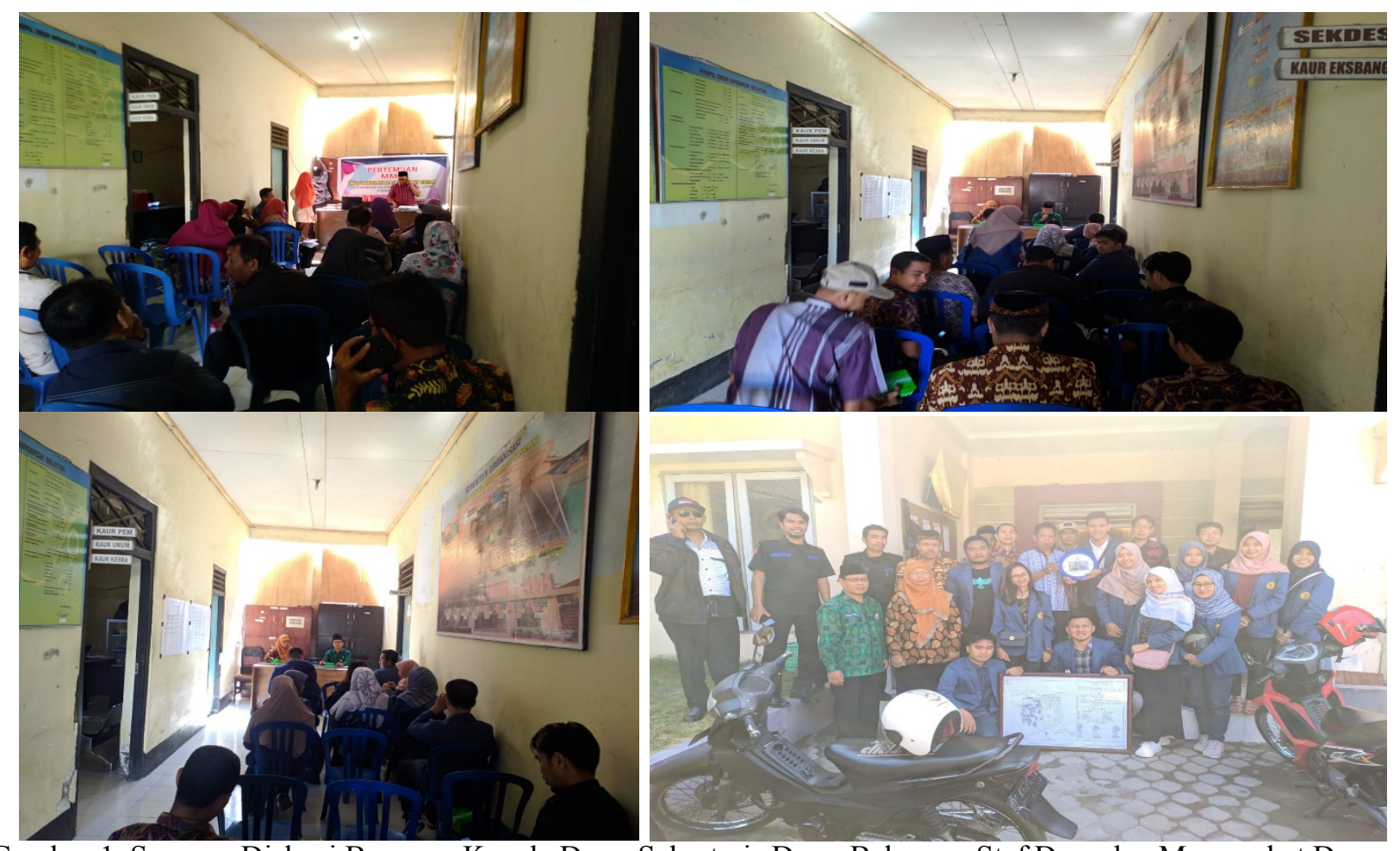

Gambar 1. Suasana Diskusi Bersama Kepala Desa, Sekertaris Desa, Beberapa Staf Desa dan Masyarakat Desa Masbagik Selatan

\subsection{Metode Perancangan Sistem}

Model Pengembangan Sistem yang digunakan pada Sistem Informasi Desa Untuk Manajemen Data Covid 19 Dan Transparansi Keuangan Dalam Peningkatan Efisiensi Birokrasi Pemerintah Desa Masbagik Selatan yaitu Metode Rapid Application Development (RAD), adalah strategi siklus hidup yang ditujukan untuk menyediakan pengembangan yang jauh lebih cepat dan mendapatkan hasil dengan kualitas yang lebih baik dibandingkan dengan hasil yang dicapai melalui siklus tradisional [8]. RAD merupakan gabungan dari bermacam-macam teknik terstruktur dengan teknik prototyping dan teknik pengembangan joint application untuk mempercepat pengembangan sistem/aplikasi [9]. Dari definisi-definisi konsep RAD ini, dapat dilihat bahwa pengembangan aplikasi dengan menggunakan metode RAD ini dapat dilakukan dalam waktu yang relatif lebih cepat.

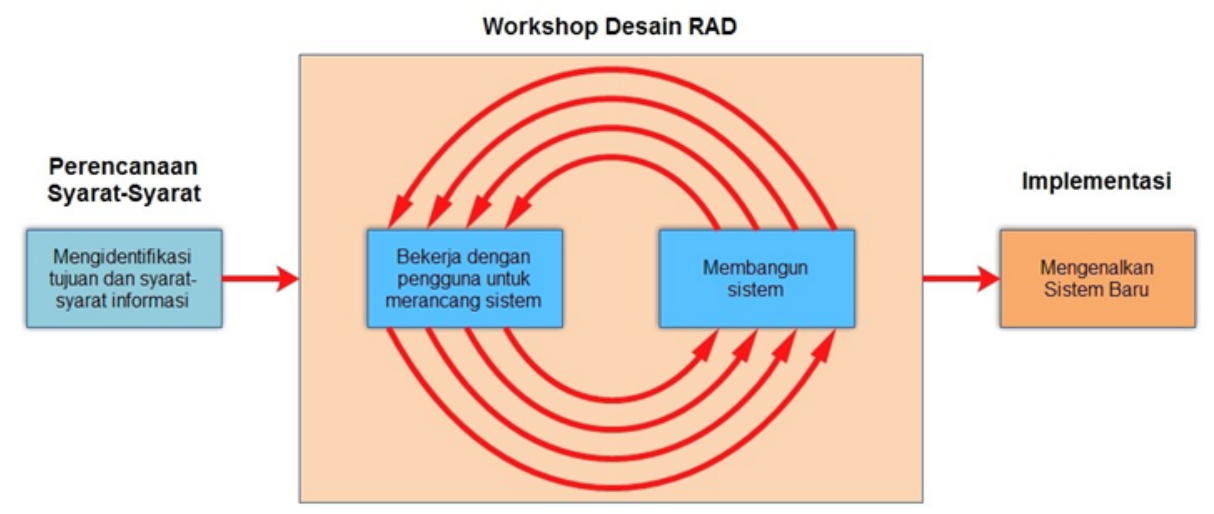

Gambar 2. Siklus Pengembangan Sistem Rapid Application Development.

berikut ini adalah tahap-tahap pengembangan aplikasi dari tiap-tiap fase pengembangan aplikasi.

a. Requirements Planning (Perencanaan bersyarat) 
Dalam fase ini, pengguna dan penganalisis bertemu untuk mengidentifikasikan tujuan-tujuan aplikasi atau sistem serta untuk mengidentifikasikan syarat-syarat informasi yang ditimbulkan dari tujuan-tujuan tersebut. Orientasi dalam fase ini adalah menyelesaikan masalah-masalah perusahaan. Meskipun teknologi informasi dan sistem bisa mengarahkan sebagian dari sistem yang diajukan, fokusnya akan selalu tetap pada upaya pencapaian tujuan-tujuan perusahaan [10].

b. RAD Design Workshop (Workshop Desain RAD)

Fase ini adalah fase untuk merancang dan memperbaiki yang bisa digambarkan sebagai workshop. Penganalisis dan dan pemrogram dapat bekerja membangun dan menunjukkan representasi visual desain dan pola kerja kepada pengguna. Workshop desain ini dapat dilakukan selama beberapa hari tergantung dari ukuran aplikasi yang akan dikembangkan. Selama workshop desain RAD, pengguna merespon prototipe yang ada dan penganalisis memperbaiki modul-modul yang dirancang berdasarkan respon pengguna [9]. Apabila seorang pengembangnya merupakan pengembang atau pengguna yang berpengalaman, Kendall menilai bahwa usaha kreatif ini dapat mendorong pengembangan sampai pada tingkat terakselerasi [10].

c. Implementation (Implementasi )

Pada fase implementasi ini, penganalisis bekerja dengan para pengguna secara intens selama workshop dan merancang aspek-aspek bisnis dan nonteknis perusahaan. Segera setelah aspek-aspek ini disetujui dan sistem-sistem dibangun dan disaring, sistem-sistem baru atau bagian dari sistem diujicoba dan kemudian diperkenalkan kepada organisasi [10].

\subsection{Desain Sistem}

Tahap perancangan Sistem Informasi Desa Untuk Manajemen Data Covid 19 Dan Transparansi Keuangan Dalam Peningkatan Efisiensi Birokrasi Pemerintah Desa Masbagik Selatan berbasis website ini menggunakan tiga diagram UML yang terdiri dari use case diagram dan activity diagram.

\subsubsection{Use Case Diagram}

Berikut ini merupakan Use Case Diagram dari Sistem Informasi Desa Untuk Manajemen Data Covid 19 Dan Transparansi Keuangan Dalam Peningkatan Efisiensi Birokrasi Pemerintah Desa Masbagik Selatan dapat dilihat pada Gambar 3.

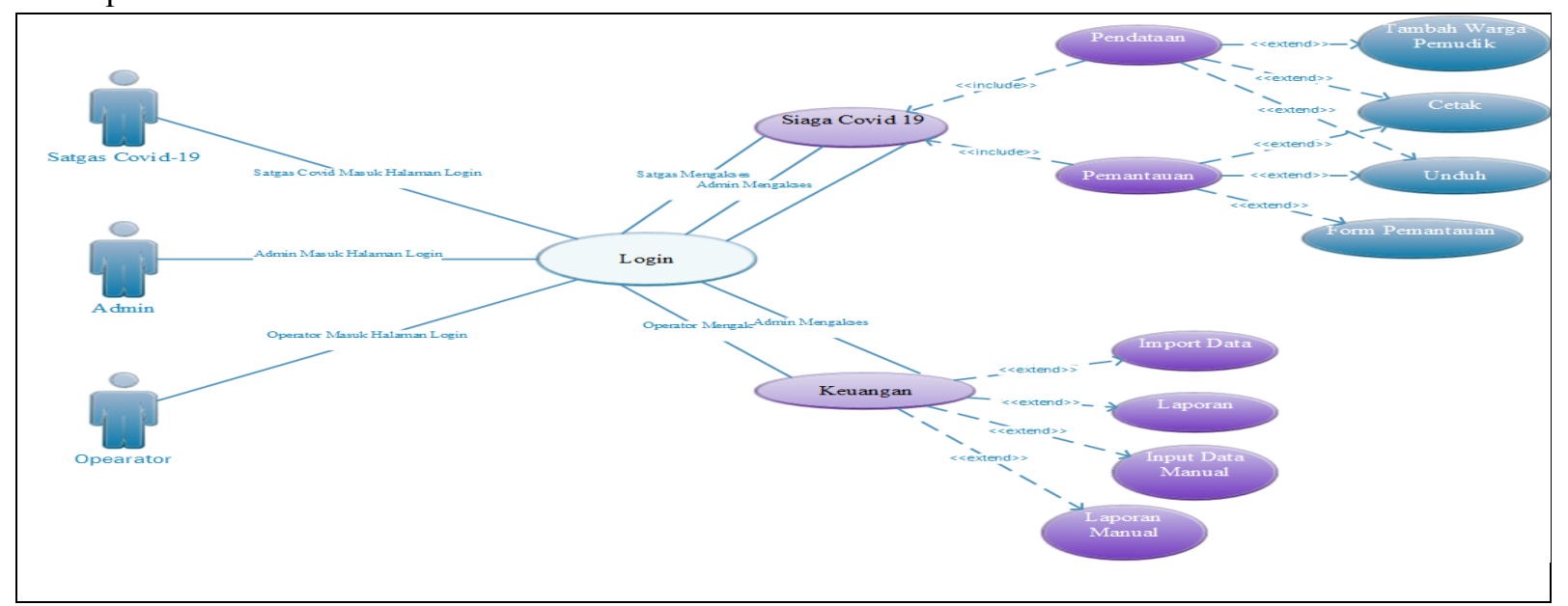

Gambar 3. Tampilan Use Case Diagram Seluruh Komponen Sistem Informasi Desa Termasuk Menu Siaga Covid 19 dan Keuangan

\subsubsection{Activity Diagram}

Berikut merupakan Activity Diagram dari Sistem Informasi Desa Untuk Manajemen Data Covid 19 Dan Transparansi Keuangan Dalam Peningkatan Efisiensi Birokrasi Pemerintah Desa Masbagik Selatan

1. Proses Login

Gambar 4 menunjukkan 3 aktor berbeda dalam aktivitas untuk masuk ke dalam sistem melalui proses login. Ketika pertama kali akses, akan ada beranda khusus untuk menampilkan form login yang harus diisi oleh Admin, Operator, maupun Satgas Covid 19 dan selanjutnya ketiga actor tersebut memasukkan username dan password sesuai dengan data yang telah didaftar didalam basis data . 


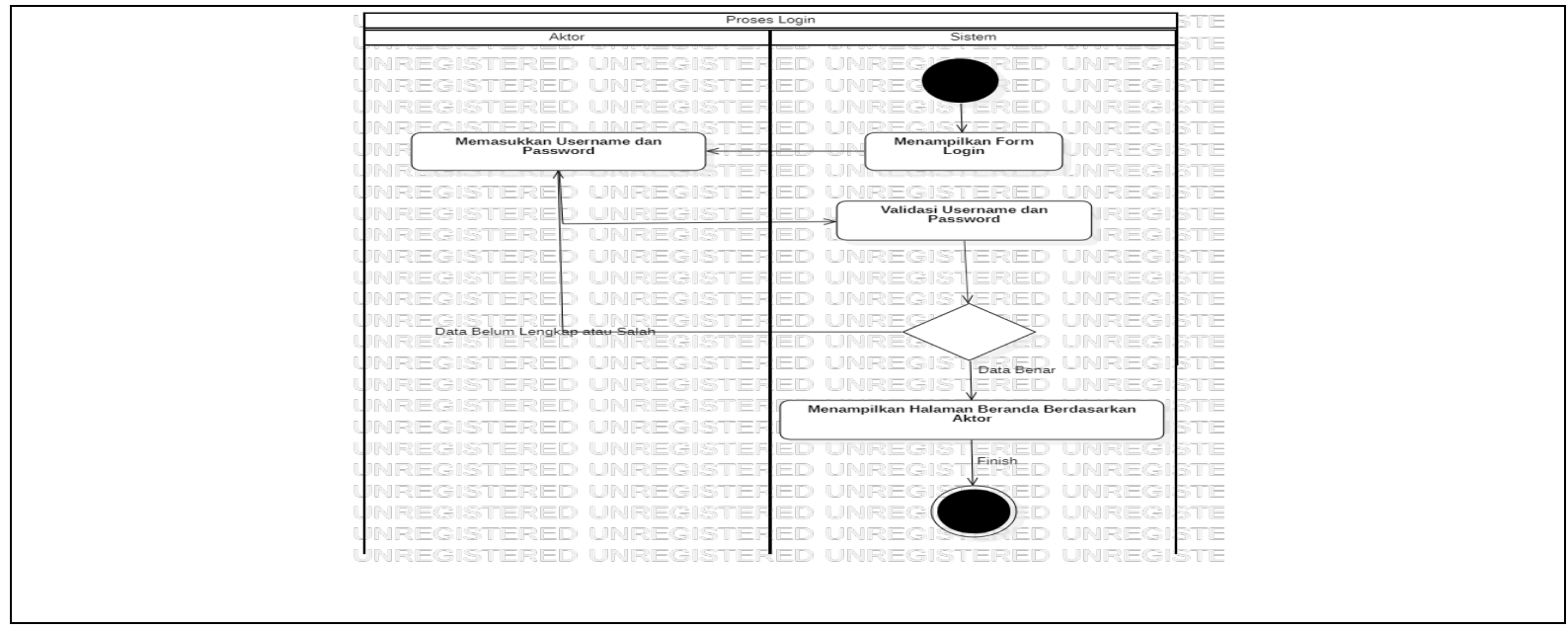

Gambar 4. Tiga Jenis aktor berbeda memasuki proses login

2. Proses Menambahkan Data Warga Pemudik Pandemi Covid 19

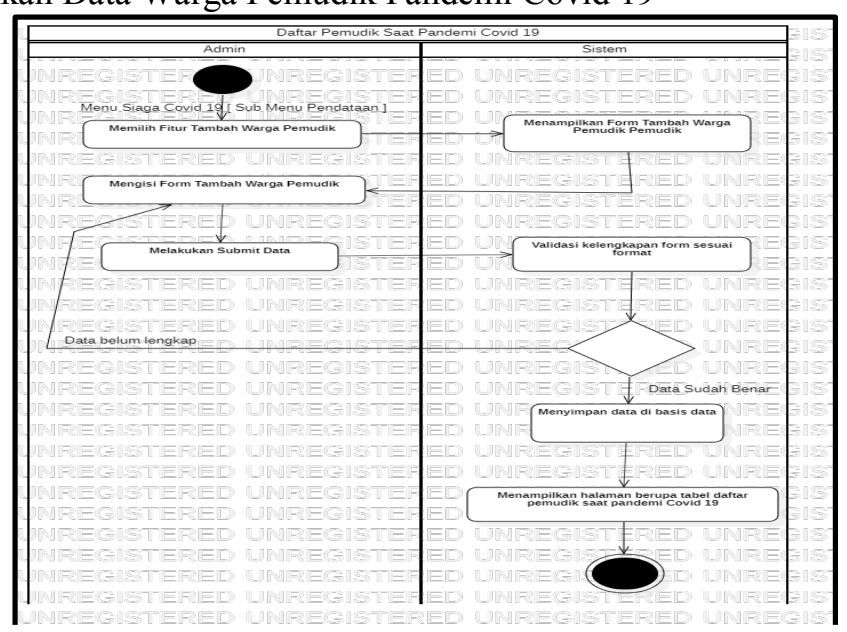

Gambar 5. Admin mengakses menu Siaga Covid 19 untuk menambahkan daftar warga pemudik dengan memilih fitur tambah warga pemudik

Gambar 5 diatas mengilustrasikan aktivitas yang terjadi apabila Admin menambahkan daftar warga pemudik dengan memilih fitur tambah warga pemudik, apabila admin telah memilih fitur tambah warga pemudik maka sistem akan menampilkan form tambah warga pemudik yang harus diisi oleh admin.

3. Proses Pengisian Pemantauan Form Pemantauan Isolasi Mandiri

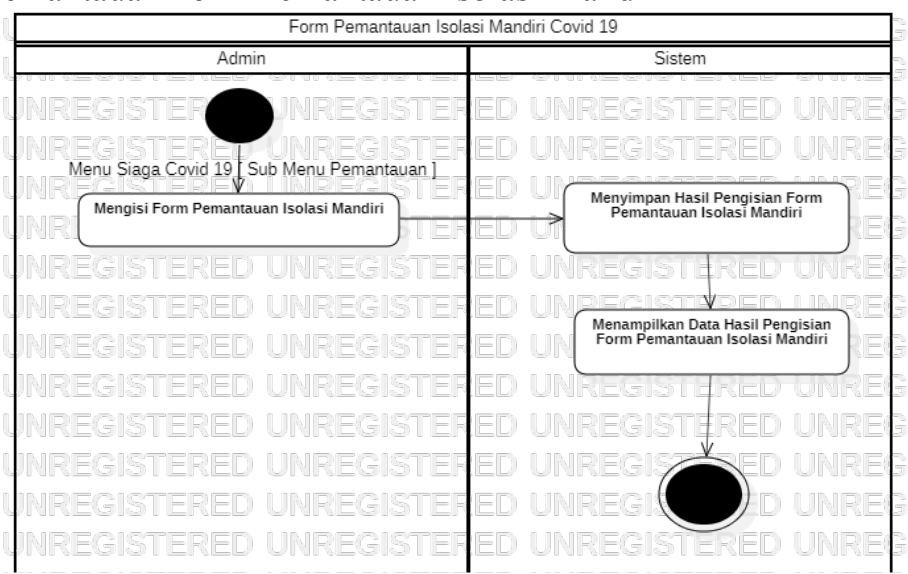

Gambar 6. Admin Mengisi Form Pemantauan Isolasi Mandiri di bagian Sub Menu Pemantauan 
Pada Gambar 6 diatas mengilustrasikan aktivitas mengenai Admin Mengisi Form Pemantauan Isolasi Mandiri pada bagian Sub Menu Pemantauan, ketika form telah terisi maka akan diproses oleh sistem dan disimpan dalam bentuk table basis data

4. Proses Pencetakan Daftar Pemantauan Isolasi Mandiri

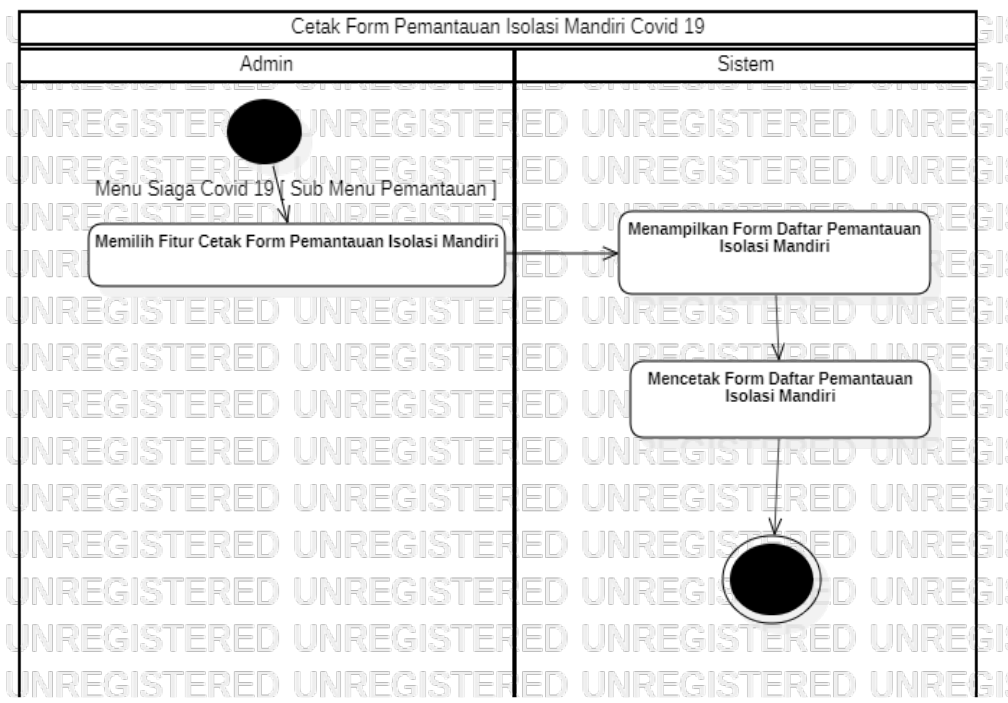

Gambar 7. Admin Mencetak Form Pemantauan Isolasi Mandiri

Pada Gambar 7 diatas mengilustrasikan aktivitas mengenai Admin Mencetak Form Pemantauan Isolasi Mandiri pada bagian Sub Menu Pemantauan. ketika telah diklik fitur cetak form pemantauan hasil isolasi mandiri maka akan ditampilkan halaman tabel daftar pemantauan isolasi mandiri dan pada akhirnya dicetak

5. Proses Download Daftar Pemantauan Isolasi Mandiri

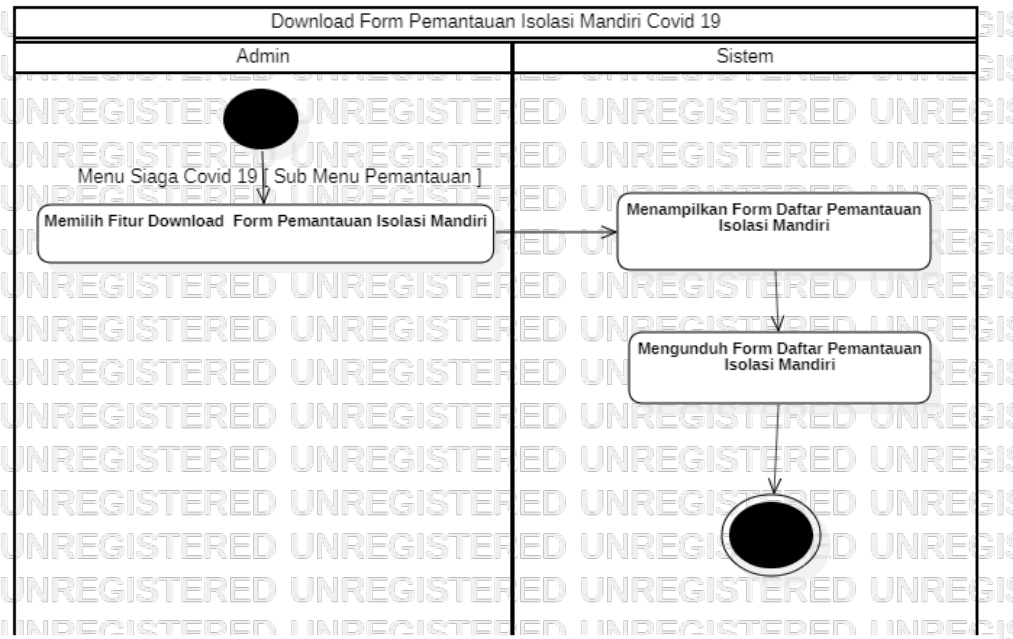

Gambar 8. Admin Mengunduh Form Pemantauan Isolasi Mandiri pada bagian Sub Menu Pemantauan

Pada Gambar 8 diatas mengilustrasikan aktivitas Admin Mengunduh Form Pemantauan Isolasi Mandiri pada bagian Sub Menu Pemantauan. Ketika Fitur Download dipilih oleh Admin maka Form Daftar Pemantauan akan ditampilkan lalu diproses kedalam bentuk format xls (Microsoft Excel) dan terunduh secara otomatis.

6. Proses Import Berkas Siskeudes

Pada Gambar 9 mengilustrasikan aktivitas mengenai Admin Meng-import Berkas Siskeudes dibagian Sub Menu Import Data Keuangan, ketika Admin telah memilih fitur import data maka akan ada tampilan jendela akses berkas siskeudes dimana harus sesuai dengan format CSV (Comma Separated Value) apabila tidak 
sesuai maka diulangi dari awal, apabila sesuai maka data akan langsung disimpan didalam tabel basis data Siskeudes.

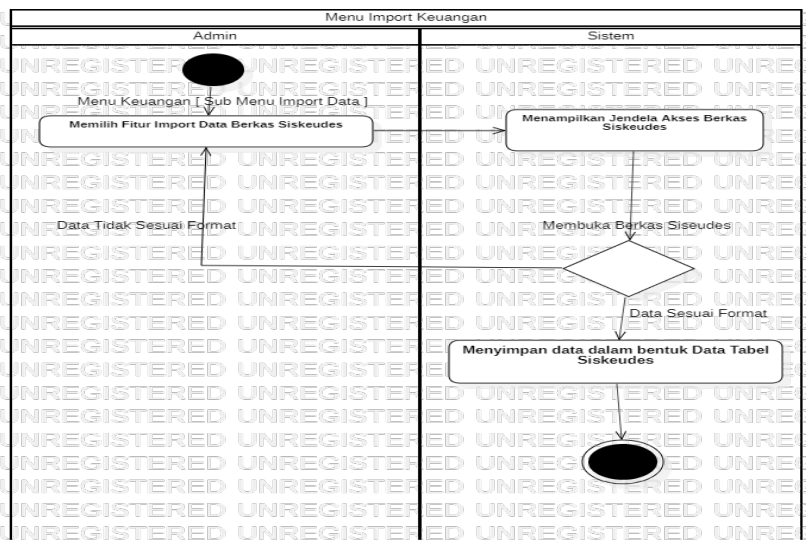

Gambar 9. Admin Mengimpor Berkas Siskeudes

7. Proses Input Data Manual Siskeudes

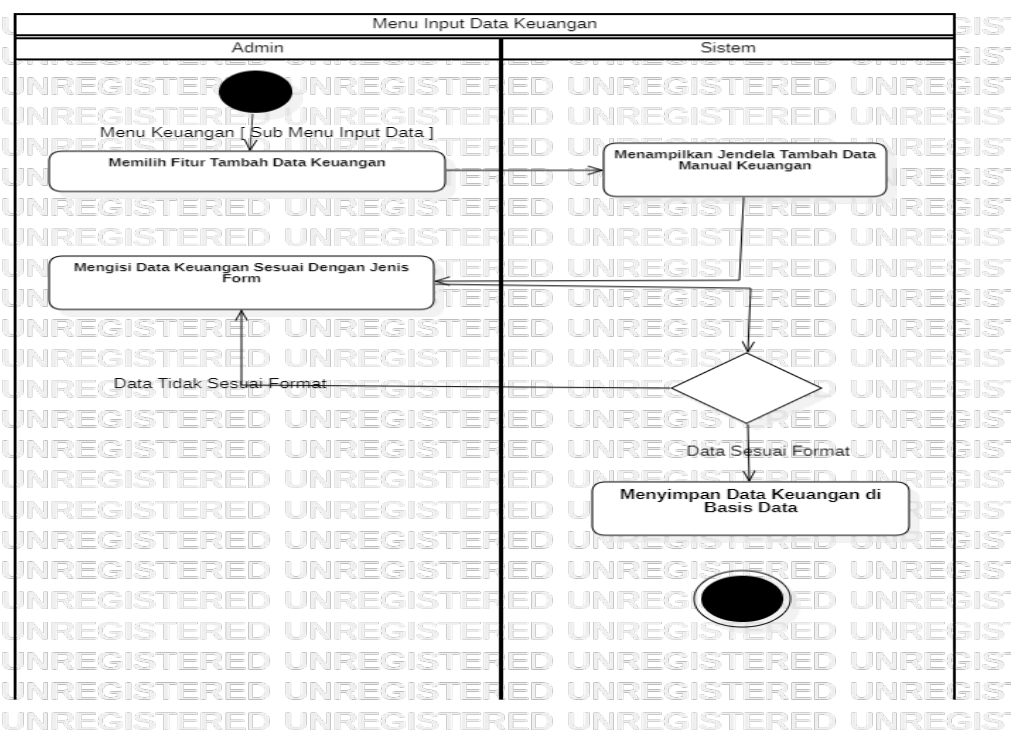

Gambar 10. Admin Memasukkan Data Keuangan Secara Manual

Pada Gambar 10 diatas mengilustrasikan aktivitas tentang Admin Memasukkan Data Keuangan secara Manual, setelah Admin memilih fitru tambah data keuangan maka sistem akan menampilkan jendela tambah data manual keuangan, lalu Admin mengisi sesuai dengan format nilai, apabila benar formatnya maka akan tersimpan oleh sistem basis data sementara jika tidak sesuai dengan format maka memulai dari awal.

\subsection{Implementasi Sistem}

Pengimplementasi Sistem Informasi Desa Untuk Manajemen Data Covid 19 Dan Transparansi Keuangan Dalam Peningkatan Efisiensi Birokrasi Pemerintah Desa Masbagik Selatan ini menggunakan PHP sebagai Bahasa pemrograman untuk sisi server-nya dan framework CodeIgniter dengan konsep M-V-C (Model-View-Controller) dalam pengembangannya. Selain itu digunakan juga XAMPP dan MySQL sebagai localhost dan database server 3.5.1. Implementasi Interface Sistem

Berikut merupakan hasil Implementasi tampilan (interface) program dari Sistem Informasi Desa Untuk Manajemen Data Covid 19 Dan Transparansi Keuangan Dalam Peningkatan Efisiensi Birokrasi Pemerintah Desa Masbagik Selatan. 
1. $\mathrm{T} \leftarrow \rightarrow \mathrm{C} \bullet$ (i) localhost/SID/indexphp/siteman

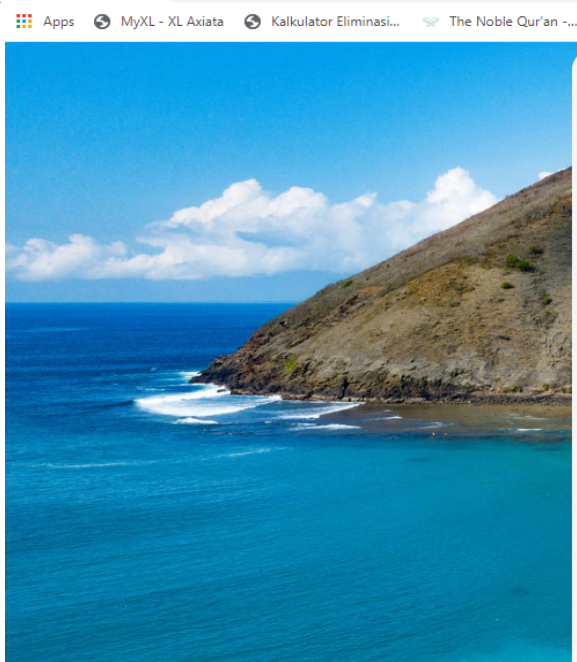

Q Madinah Taraweeh... E Abdur-Rahman as....

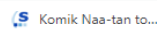

(5) Fujimura-kun Mate.

0 เ $ค *$ *
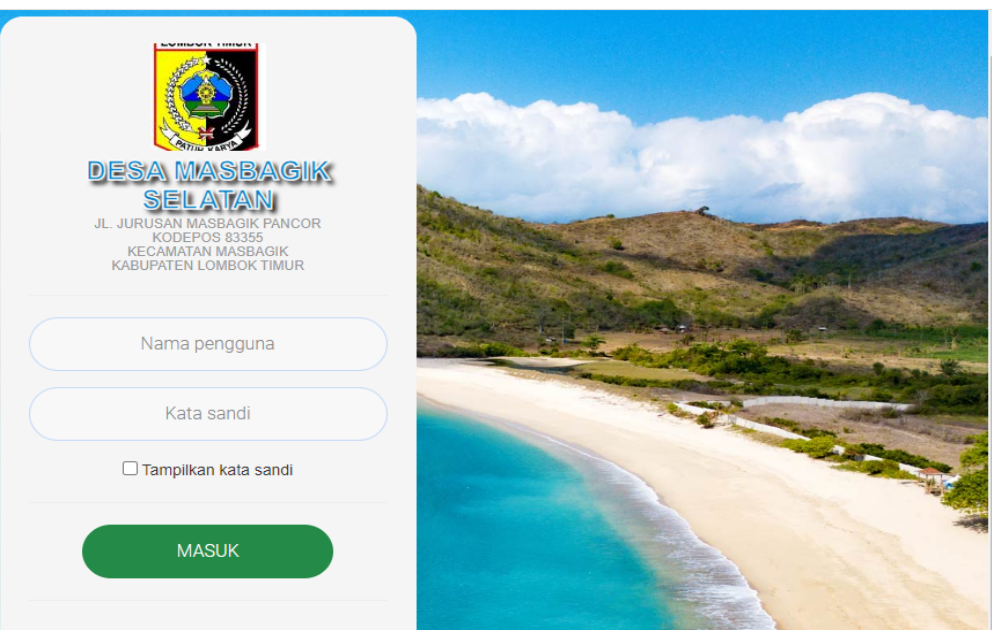

Gambar 11. Tampilan Login Sistem Informasi Desa

Pada Gambar 11 diatas merupakan hasil implementasi dari sistem informasi Desa Untuk Manajemen Data Covid 19 Dan Transparansi Keuangan Dalam Peningkatan Efisiensi Birokrasi Pemerintah Desa Masbagik Selatan, Halaman ini merupakan tampilan ketika pengguna ingin mengakses administrasi untuk bisa masuk kedalam system. Untuk masuk ke dalam sistem perlu memasukkan username dan password yang sesuai dengan data di database.

2. Tampilan Menu Siaga Covid 19 Bagian Sub Menu Pendataan

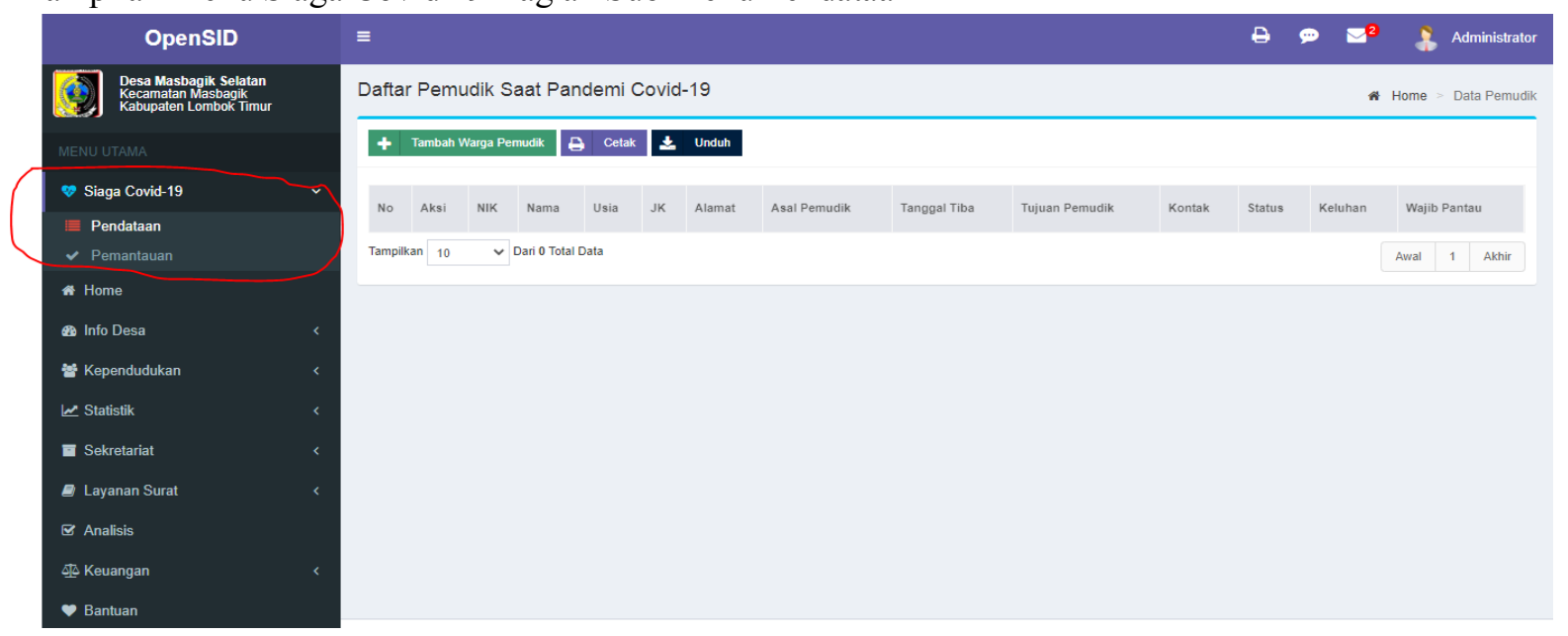

Gambar 12. Menu Siaga Covid 19 Bagian Pendataan

Pada Gambar 12 diatas menampilkan Implementasi dari Fitur Menu Siaga Covid 19, pada bagian sub menu Pendataan disini memperlihatkan beberapa fungsi yaitu Tambah Warga Pemudik, Cetak, dan Unduh, dimana Fungsi ini akan menambahkan Daftar Pemudik Saat Pandemi Covid-19, Mencetak Daftar dan terakhir Mengunduh data dalam bentuk format xls (Microsoft Excel).

3. Tampilan Form Tambah Warga Pemudik

Pada Gambar 13 menampilkan Form Tambah Warga Pemudik yang memasuki dan keluar dari wilayah Desa Masbagik Selatan dimana ada beberapa yang harus diisi seperti NIK/ Nama, apabila bukan penduduk asli maka ada tambah penduduk non domisili / tidak tetap, serta ada beberapa hal lain seperti Asal Pemudik, Tujuan Pemudik, Kontak Pemudik, Status Covid, Apakah Wajib Dipantau, Keluhan Kesehatan, Email, Tanggal, dan terakhir Keterangan Pemudik. 


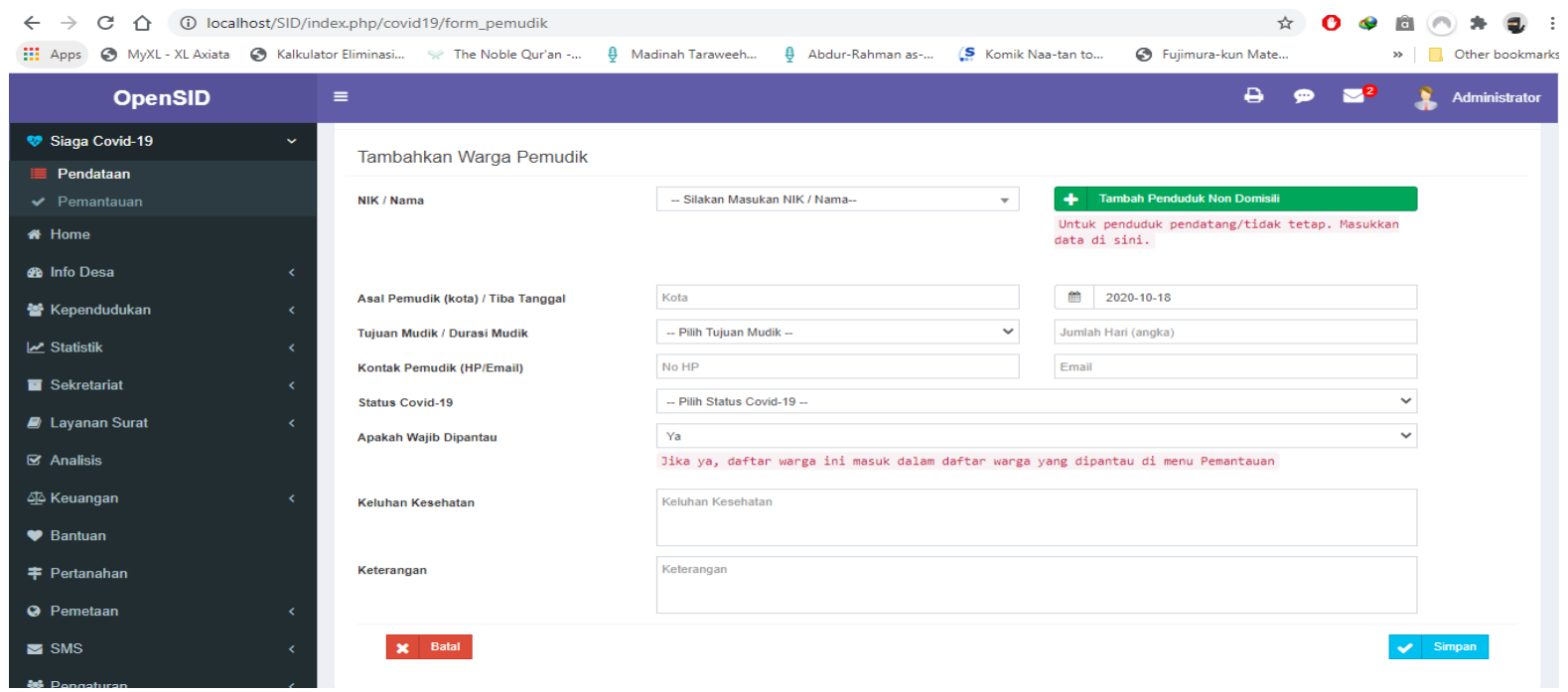

Gambar 13. Tampilan Form Tambah Warga Pemudik

4. Tampilan Fitur Import Berkas Siskeudes

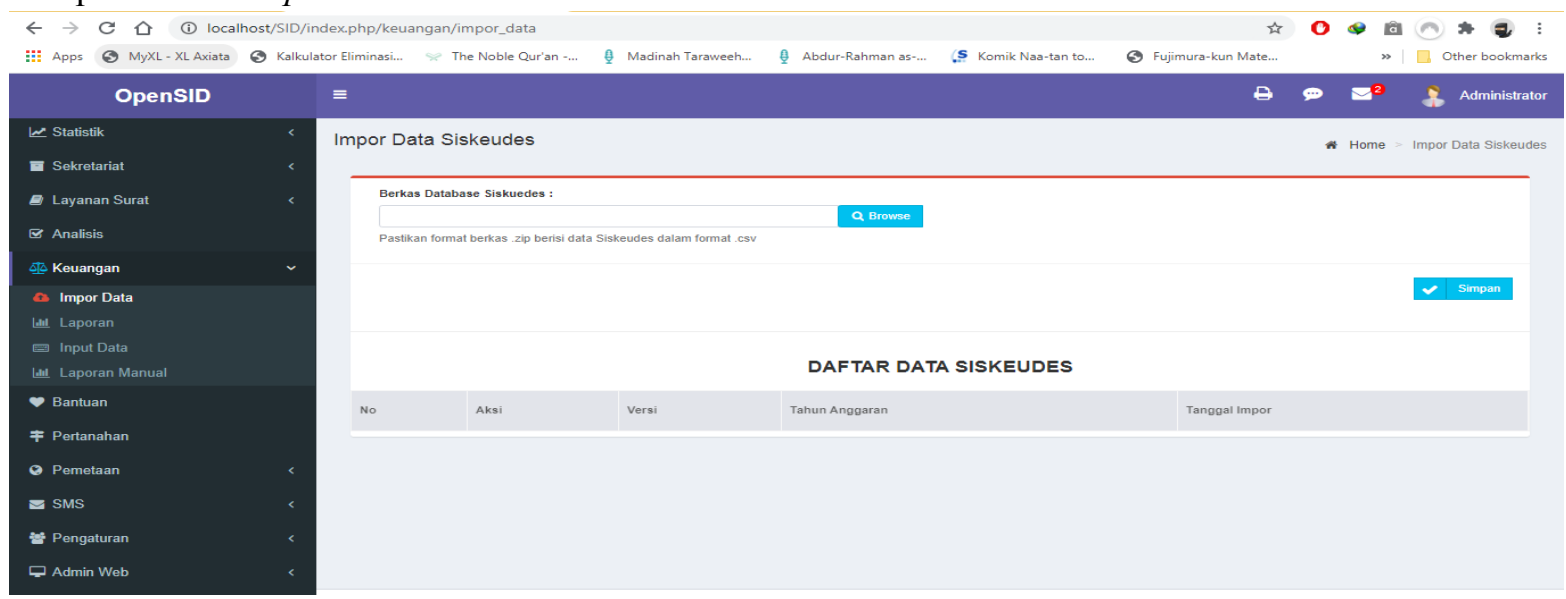

Gambar 14. Tampilan Import Berkas Fitur Siskeudes

Pada Gambar 14 diatas ini menampilkan fitur import berkas siskeudes dimana fitur ini akan membuka berkas file berisi data keuangan yang telah disusun sebelumnya dalam bentuk MDB (Microsoft Access Database) menjadi format sesuai dengan sistem yaitu CSV (Comma Separated value), jika format tidak sesuai maka sistem akan memulai ulang dari awal

5. Tampilan Input Data Keuangan Manual

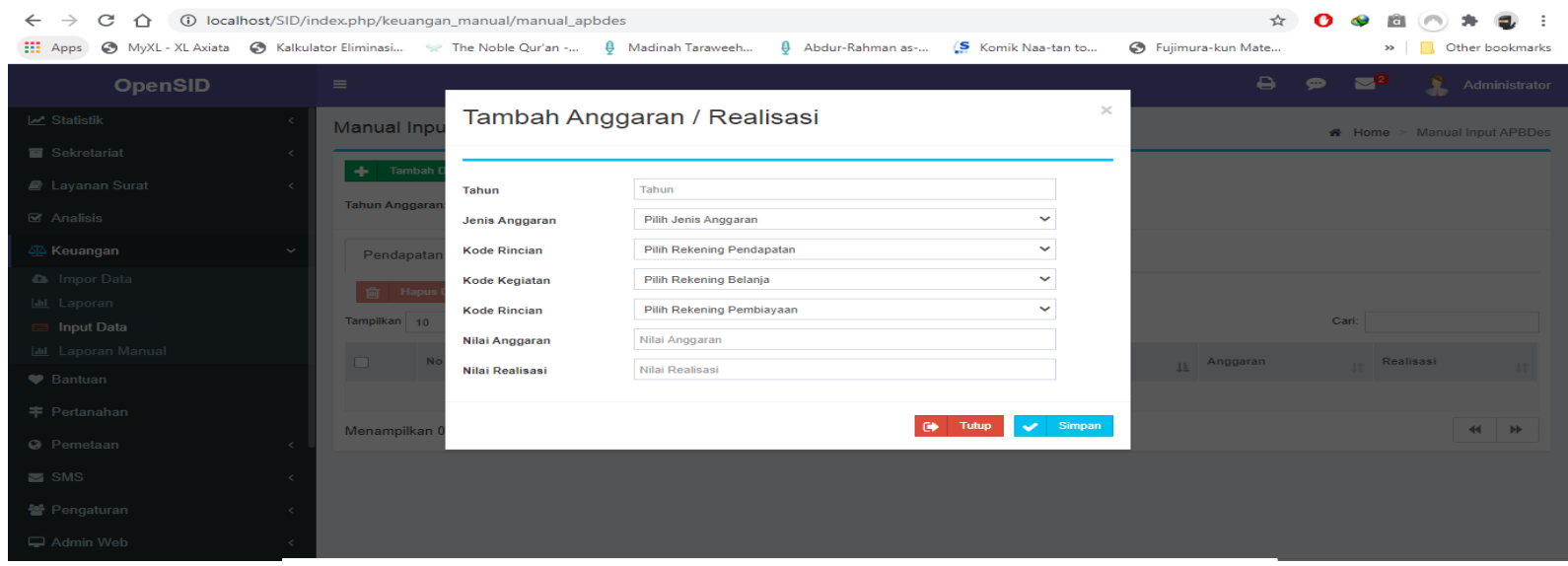

Gambar 15. Tampilan Input Manual Data Keuangan 
Pada Gambar 15 diatas merupakan Tampilan Input Manual Data keuangan dimana Admin atau Operator bisa memasukkan data keuangan secara manual sesuai dengan format Siskeudes yang telah ditetapkan di peraturan dalam negeri nomor 20 tahun 2018 tentang Pengelolaan Keuangan Desa tepatnya di pasal 57 ayat (2) tentang hak masyarakat mendapatkan informasi seperti Laporan Realisasi Keuangan APBDes, Laporan Realisasi Kegiatan, serta Sisa Anggaran

\section{HaSil dan PEMBahasan}

Penulis melaksanakan uji coba bagi aplikasi yang telah dibuat dengan memberikan kuisioner kepada 10 orang responden yang merupakan pegawai Kantor Desa Masbagik Selatan. Hal ini ditujukan untuk mengetahui apakah sistem sudah berfungsi dengan baik sebagai material hasil evaluasi sistem. Pilihan jawaban kuisioner terdiri dari 5 kategori yaitu Sangat Setuju (SS), Setuju (S), Biasa Saja (BS), Tidak Setuju (TS) dan Sangat Tidak Setuju (STS).

Berikut ini parameter dan hasil dari pengujian yang dilakukan terhadap 10 responden yang merupakan pegawai Kantor Desa Masbagik Selatan.

\begin{tabular}{|r|l|r|r|r|r|r|}
\hline \multirow{2}{*}{ No } & \multicolumn{3}{|c|}{ Pernyataan } & \multicolumn{3}{|c|}{ Jawaban } \\
\cline { 3 - 6 } & & \multicolumn{1}{|c|}{ SS } & \multicolumn{1}{|c|}{ S } & BS & TS & STS \\
\hline 1 & Tampilan Sistem Sudah Sangat Baik dan Mudah Digunakan & 7 & 3 & 0 & 0 & 0 \\
2 & Sistem Mempermudah Pekerjaan Pegawai & 8 & 2 & 0 & 0 & 0 \\
3 & Sistem Sudah Bekerja Sesuai Dengan Fungsinya & 6 & 4 & 0 & 0 & 0 \\
4 & Sistem Dapat Menghasilkan Keluaran berupa Data Persebaran & & & & & \\
& Covid-19 dan Keuangan Desa & 6 & 4 & 0 & 0 & 0 \\
5 & Sistem Sudah Sesuai Dengan Kebutuhan Instansi & 5 & 5 & 0 & 0 & 0 \\
\hline \multicolumn{2}{|c|}{ Total } & 32 & 18 & & & \\
\hline \multicolumn{2}{|c|}{ Persentase } & $64 \%$ & $36 \%$ & & & \\
\hline
\end{tabular}

Berdasarkan hasil kuisioner terhadap 10 responden mengenai kepuasan penggunaan Sistem Informasi Desa Untuk Manajemen Data Covid 19 Dan Transparansi Keuangan Dalam Peningkatan Efisiensi Birokrasi Pemerintah Desa Masbagik Selatan yang telah dilakukan, maka didapatkan persentase hasil dari pernyataan responden yaitu Sangat Setuju sebesar 64\% atau sebanyak 32 poin dan responden yang memilih setuju sebanyak $36 \%$ atau 18 poin.

\section{KESIMPULAN DAN SARAN}

\subsection{Kesimpulan}

1. Perancangan Sistem Informasi Desa Untuk Manajemen Data Covid 19 Dan Transparansi Keuangan Dalam Peningkatan Efisiensi Birokrasi Pemerintah Desa Masbagik Selatan ini telah diselesaikan dengan baik sesuai hasil analisis terhadap kebutuhan lingkungan kerja di Kantor Desa Masbagik Selatan

2. Pembuatan Sistem Informasi Desa Untuk Manajemen Data Covid 19 Dan Transparansi Keuangan ini dapat membantu pengolahan data dalam bentuk daftar persebaran warga pemudik yang terpantau dan juga data keuangan APBDes secara efektif dan efisien karena telah menggunakan sistem basis data sehingga meminimalisir terjadinya kesalahan dan kehilangan data , serta menghasilkan perbaikan kualitas layanan informasi dan menciptakan transparansi keuangan APBDes Masyarakat Desa Masbagik Selatan.

3. Berdasarkan hasil kuisioner pengujian sistem dengan respondensi pegawai Kantor Desa Masbagik Selatan, didapatkan $70 \%$ responden sangat setuju bahwa tampilan sistem sudah sangat baik dan mudah digunakan, $80 \%$ responden sangat setuju sistem mempermudah pekerjaan staff/pegawai, $60 \%$ responden sangat setuju sistem sudah bekerja sesuai fungsinya, $60 \%$ responden sangat setuju sistem dapat menghasilkan keluaran berupa data persebaran Covid-19 dan keuangan desa, dan 50\% responden sangat setuju bahwa sistem sudah sesuai dengan kebutuhan instansi Pemerintahan Desa Masbagik Selatan. Sehingga dapat disimpulkan bahwasannya sistem yang dibuat memiliki kemampuan yang baik apabila diimplementasikan secara online, karena mampu membantu pegawai dalam melaksanakan pekerjaan dengan adanya Manajemen Data Persebaran Covid-19 dan Sistem Keuangan Desa

\subsection{Saran}


1. Sistem Informasi Desa ini diharapkan kedepannya dapat memasukkan data keuangan secara banyak dengan meng-import langsung dengan format xls (Excel) bukan dengan menggunakan format mdb (Access Database)

2. Untuk pengembangan selanjutnya terutama fitur keuangan desa agar bisa terhubung langsung dengan Siskeudes Induk di Kementrian Dalam Negeri

\section{DAFTAR PUSTAKA}

[1] Faisal Al Isfahani, Fuji Nugraha, dan Rifki Mubarok, "Implementasi Web Service untuk Aplikasi Pemantau Coronavirus Disase 2019 (COVID 19)", Innovation in Research of Informatics., vol.2, no. 1, hal. 33-39,2019.

[2] I Gusti Ayu Trisha Sulina dan Made Arie Wahyuni, "Peranan Sistem Keuangan Desa (SISKEUDES) Terhadap Kinerja Pemerintah Desa", e-Journal S1 Ak Universitas Pendidikan Ganesha., vol.8, no.2, hal. 121-130,2017.

[3] A. Kadir, Pengenalan Sistem Informasi. Yogyakarta: CV. Andi Offset, 2014.

[4] A. Kristanto, Perancangan SI dan Aplikasinya. Yogyakarta: Penerbit Gava Media, 2003.

[5] M. R. Arief, Pemrograman Web Dinamis Menggunakan PHP \& MySQL. Yogyakarta: Andi, 2011.

[6] D. M. Harja, S. E. Anjarwani dan A. Zubaidi, "Sistem Informasi Koperasi Pegawai Negeri (KPN) Universitas Mataram Berbasis Web," J-COSINE, Vol.2, No.2, Desember 2018.

[7] B. Sidik, Pemrograman Web dengan PHP. Bandung: Informatika, 2012.

[8] Mc.,Leod, R. Jr. 2002. System Development: A Project Management Approach. New York: Leigh Publishing LLC.

[9] Whitten, J.L. \& Bentley, L.D. 2004. System Analysis \& Design Methods: Sixth Edition. New York: Mc.Graw-Hill.

[10] Kendall, J.E. \& Kendall, K.E. 2010. Analisis dan Perancangan Sistem. Jakarta: Indeks. 